\title{
The effect of integrated flipped classroom with local cultural values on character building in higher education
}

Asham Bin Jamaluddin, Universitas Negeri Malang, Indonesia, ashambj@gmail.com ORCID: 0000-00030562-072X;

*Siti Zubaidah, Universitas Negeri Malang, Indonesia, siti.zubaidah.fmipa@um.ac.id ORCID: 0000-00020718-6392;

Susriyati Mahanal, Universitas Negeri Malang, Indonesia, susriyati.mahanal.fmipa@um.ac.id ORCID: 0000-0001-5764-2184;

Abdul Gofur, Universitas Negeri Malang, Indonesia, abdul.gofur.fmipa@um.ac.id ORCID: 0000-0002-93897536

* Corresponding Author

\begin{abstract}
This study aimed to investigate the effect of Integrated Flipped Classroom with Local Cultural Values (FCLCV) on student character. This quasi-experiment used a pretest-posttest non-equivalent control group design. It involved 102 students from Universitas Negeri Makassar, Indonesia. The data of the study were obtained through observations and analyzed using descriptive and inferential statistics (One-Way ANCOVA). The statistical analyses showed that FCLCV had an effect on student character, where the mean score achieved by students in the FCLCV group was higher than those achieved by students in the Flipped Classroom (FC) and Conventional (Direct Learning) groups. Therefore, local cultural values can be integrated into a technology-based instructional model to foster and enhance student character.
\end{abstract}

Keywords: Flipped classroom, local cultural values, character Received: 04.12.2020 Accepted: 20.01.2021

Published: 01.02.2021

\section{INTRODUCTION}

Science and technology advancement has contributed significantly to education (Wang, Jou, Lv, \& Huang, 2018). Technology facilitates the educational process and enables students to reach the desired knowledge (Santikarn \& Wichadee, 2018; Sengel, 2016). The use of technology in the classroom can create a learning environment that is much richer and more potential to improve the quality of learning (Hsieh, Wu, \& Marzek, 2017). Therefore, the use of technology in Indonesia's learning process is always prioritized to improve learning quality. The advantages of applying technology to Indonesia's learning process can be seen in the implementation of flipped classrooms (Abdullah, Hussin, \& Ismail, 2019; Zainuddin \& Perera, 2017).

Flipped Classroom (FC) involves the process where students take advantage of technology to activate initial knowledge before class, understand the in-depth information while in class, and review material that has been studied at home (Abdullah et al., 2019; Awidi \& Paynter, 2019; Leo \& Puzio, 2016). FC facilitates students to learn in a constructivist manner, which leads to a meaningful learning process (Wang et al., 2018). This model allows students to focus more on discussing fundamental points while in the classroom with peers and educators to practice thinking skills (Hsieh et al., 2017). Also, the learning process in $\mathrm{FC}$, such as problem solving with discussion, presentation, and question and answer, can support the building of character values such as tolerance, hard work, and responsibility, as well as the appreciation of the use of better technology in the learning process (Akçayir \& Akçayir, 2018). Therefore, FC is one of Indonesia's blended learning process (Kustandi, Warhahadibraka, Fadhillah, Suprayekti, \& Nursetyo, 2020). However, FC aims only at developing certain characters, while the role of a character as a whole is very important in education (Zarouk, Olivera, Peres, \& Khaldi, 2020).

Character is one of the main goals of education besides literacy and competence. Character is a way of thinking and behaving that can be shaped over time (Lickona, 1991). Positive character enhances a person's qualities and helps him/her to do good things (Kelemen, Matthews, \& Breevaart, 2020). The character will always be at the forefront of maintaining and sustaining the nation's strength to face every change and challenge globally (Choli \& Raihan, 2020; Komalasari \& Saripuddin, 2018). Individuals with good character understand moral concepts and attitudes and are able to demonstrate good moral behavior in their environment (Hidayati, Waluyo, Winarni, \& Suyitno, 2020). Therefore, character- 
building must be fought for through character education to avoid character problems and crises. However, there are still discrepancies between expectations and reality in terms of character in the field.

Character problems and crises are caused by several factors, such as using inappropriate models and strategies in learning, the lack of attention of educators to character building, and the ignorance of the importance of embedding cultural values in learning. They were also caused by the misuse of technology that widen the gap between the desired and achieved results in character building (Christen, 2018; Silay, 2013; Umami, Gani, \& Waskito, 2019). Character crises can also result from a decline in ethics and changes in how Indonesian students live their lives, which are likely to resemble foreign lifestyles contrary to the local values. Sadly, more and more young people fall for the world's harmful trends through technology (Isawi, AlAhmad, Alsaadi, \& Samkari, 2019). Students shamelessly cheat on the exams, plagiarize their assignments, create and view inappropriate content on their gadgets (Judi, Ashaari, Azan, Zin, \& Yusof, 2013; Komalasari \& Saripuddin, 2017; Taufiqurrahman, 2018). The indirect impacts include the disappearance of honesty, tolerance and the emergence of individualism, insecurity, and lack of mutual respect among students in the classroom (Mislia, Mahmud, \& Manda, 2016; Suyatno, Jumintono, Pambudi, Mardati, \& Wantini, 2019; Taufiqurrahman, 2018). Therefore, it is feared that other problems and deviations and technology such as in the FC can exacerbate the character crises. In general, if these continue to happen, the quality of human resources in Indonesia, especially students, can be affected. One solution is to integrate local cultural values into learning in schools or universities (Akib, 2016).

Local cultural values that are positive and educative can be integrated into education (Khan, Asif, Hashmi, \& Azeddou, 2017). UNESCO emphasizes that incorporating cultural values into teaching is important and cultural values should not be separated from learning in schools or universities. A culture that contains educational values can significantly contribute to both students and educators (Arsih, Zubaidah, Suwono, \& Gofur, 2019). Integrating cultural values into the classroom can optimally encourage the development of ethics, social, motivation, and competence in students (Christen, 2018). It has been proven that educative cultural values play an essential role in education worldwide (Lo, Fu, Lee, \& Cameron, 2019), including in Indonesia (Arwita, Amin, Susilo, \& Zubaidah, 2017; Suastra, 2017; Suyitno, Zaenuri, Sugiharti, Suyitno, \& Baba, 2019). Indonesia, especially South Sulawesi, is rich in educating cultural values that can be integrated into learning.

The people uphold the values in the Makassar-Buginese culture because they have been used as the main foundation of character building since 1373 (Unru, 2018). These values include work ethic, honesty, mutual respect, responsibility, discipline, and confidence (Abbas, 2013). These cultural values' embodiment is a strong driving force for achievement in life (Ristiana, Amin, Zubaidah, Heni, \& Al, 2017). The Makassar-Buginese cultural values can also ignite and nurture the enthusiasm and spirit of hardworking learners, laying the foundation for life-long learning (Akib, 2016). Therefore, these values should be integrated into education.

Based on the description above, it is obvious that cultural values' positive values can be used as filters and tools in shaping student character. Also, since FC presents the advantages of using technology during the learning process, it is appropriate to support Indonesia's learning process. However, the existing FC models require some modifications in character building so that the resulting instructional models become much more effective in shaping the character of students in Indonesia. According to Suhirman \& Yusuf (2020), learning needs to be enriched and combined with character education. Therefore, an Integrated Flipped Classroom with Local Culture Values (FCLCV) was implemented in this study to investigate its effect on student character in Makassar, Indonesia.

\section{THEORETICAL REVIEW}

\section{Flipped Classroom}

Flipped Classroom (FC) is a type of student-centered blended learning (Leo \& Puzio, 2016) that adheres to a constructive learning paradigm. Flipped Classroom allows students to learn outside the classroom to provide initial knowledge assisted by technology and perfect that knowledge while in the classroom (Erbil \& Kocabas, 2019; Munir, Baroutian, Young, \& Carter, 2018). It is not only oriented towards learning outcomes, but also towards promoting critical thinking, creative, communicating and collaborating skills in students (Zainuddin \& Perera, 2017; Zarouk et al., 2020), that can be obtained from problem solving activity, discussion, question and answer sessions, presentation, and independent study inside and outside of the classroom (online). The learning process in FC begins with students learning independently before classvia a technology platform designed by the lecture, followed by a collaborative learning activity conducted by the students to solve problems in class, and ends with reviewing the lesson and doing assignments while in class. The FC learning process can be seen in Figure 1. 

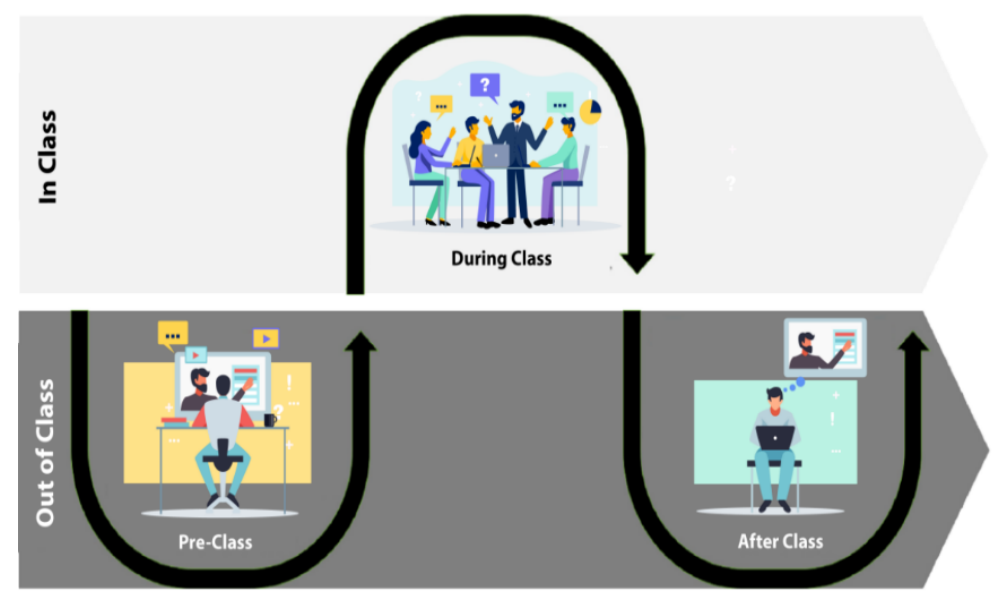

Figure 1. The design of flipped classroom learning

Implementing the Flipped Classroom (FC) can be assisted by a technological tool designed by the lecturer. Typically, FC involves Google Classroom, Moodle, Edmodo, Schoology, and other Learning Management System (LMS) platforms to conduct learning. Compared to other LMS platforms, Edmodo is considered more practical, free, and fun. Research shows that students have positive attitudes towards Edmodo's use in the classroom (Santikarn \& Wichadee, 2018). Lecturers can provide students with preclass (online) learning materials (module, video, and article), quizzes, or assignments via Edmodo. Edmodo can also be used to support in- or after-class learning processes. Edmodo's interface can be seen in Figure 2.

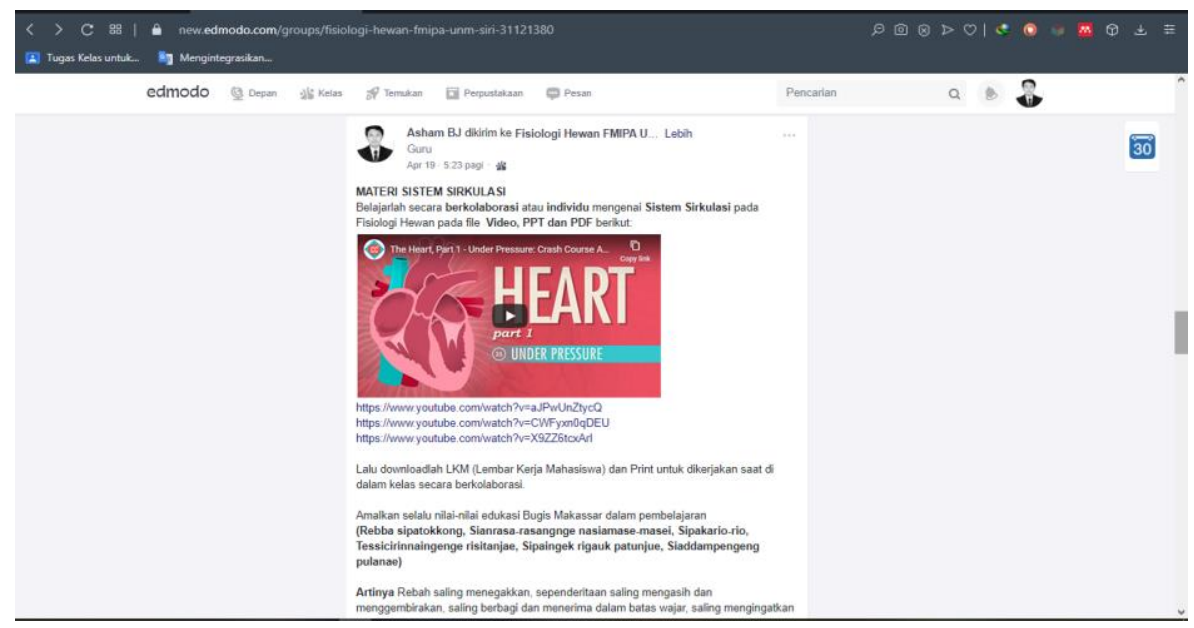

Figure 2. The interface of edmodo used in learning

\section{Local Cultural Values}

Local cultural values are the educative values found in a particular cultural area. The integration of local cultural values into education is commonly known as ethnopedagogy (Hidayati et al., 2020). Indonesia is rich with cultures of which values can be integrated into learning. One example is the Makassar-Buginese culture that contains various advice and teachings that have helped shape the community's character since hundreds of years ago (Mattulada, 2015). The spirit or the main core of the Makassar-Buginese culture's educational values is "Shame" or "Self-Esteem" maintained by an individual who is always motivated to be a better human being. The Makassar-Buginese culture is abstract, but one can feel its values and use them as a strategy to improve character and thought processes.

The teachings in the Makassar-Buginese culture can strengthen characters such as courage, honesty, unity, self-confidence, responsibility, discipline, and spirituality (Abbas, 2013; Sikki, Rijal, Nasruddin, \& Alam, 1998). Also, the educational values' impact is a self-esteem bet; thus, the MakassarBuginese people always display a process of hard work, a sense of politeness and tolerance, and a positive life goal (Hamid, Farid, Mattulada, Lopa, \& Salombe, 2003). Agustang's research (2018) supports this statement, which states that the Makassar-Buginese culture is the main foundation for behavior in a society that creates a positive atmosphere in the environment. The educational values of the Makassar- 
Buginese culture can also be the primary shield against bad deeds. Therefore, high enthusiasm and good behavior are the key values believed by the Makassar-Buginese community in achieving something, besides always prioritizing a sense of humanity (Akib, 2016). These educational values are written on the ancient Lontara script shown in Figure 3, Figure 4, Figures 5 and 6.

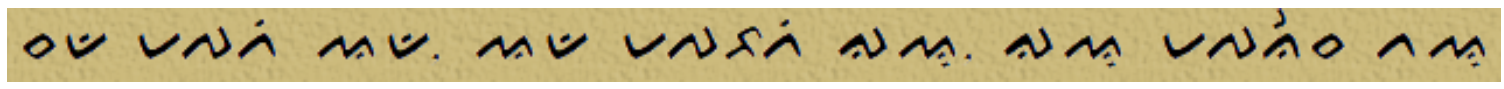

(Sadda mappati ada,ada mappabati gau,gau mappanessa tau)

Translation: Sound gives birth to words, words shape behavior, behavior establishes himself as a human being.

Figure 3. Lontara script that contains educational values (behavior)

\section{WM MMMA ONA. MAA NAOSM OSM ARSMA UAMRM}

(Dua uwala sappo, ungganna panasae sibawa nabelo kanukue)

Translation: Honesty is chastity that can lead to peace, security, safety, and success in life

Figure 4. Lontara script that contains educational values (honesty)

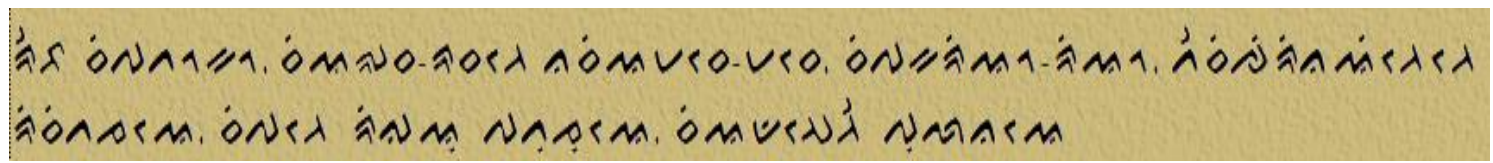

(Rebba sipatokkong, sianrasa-rasangnge nasiamase-masei, sipakario-rio,

Tessicirinnaingenge risitanjae, sipaingek rigauk patunjue, siaddampengeng pulanae)

Translation: If falling, upholding each other. If suffering, loving, and encouraging each other. Sharing and accepting each other within reasonable limits. Reminding each other of the truth and forgiving each other.

Figure 5. Lontara script that contains educational values (unity)

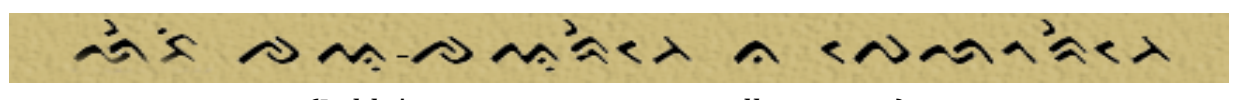

(Lebbi' cau-caurengnge na pellorengnge)

Translation: It is better to lose and fail to be better than to be safe but cannot move forward

Figure 6. Lontara script that contains educational values (courage)

The ancient Lontara scripts found in Figure 3, Figure 4, Figure 5, and Figure 6 show only small parts of thousands of educational quotes and teachings that can be applied to shape one's character from generation to generation. This advice and teachings are very much needed, especially in schools and colleges' educational environment to support character building. Therefore, the teachings that contain educational values from the Makassar-Buginese culture should be applied in the classroom. One Lontara script can teach more than one value or instructions integrated into education (Mattulada, 2015). In general, the educational values found in the Lontara scripts include teppe (faith), pesse (compassion), lempuk (honesty, straightening deeds and intentions), sipakatau (humanizing humans), sipakalebbi (glorifying humans), sipakainge (mutual reminding), sipatokkong (mutual help and mutual support), tongeng (sincerity), reso (hard work), and abbulosibatang (collaboration).

\section{An integrated flipped classroom with local cultural values (FCLCV)}

The educational values contained in the Makassar-Buginese local culture can be integrated into a Flipped Classroom (FC). These educational values can be incorporated into the timeline and Student Worksheet found on the Edmodo platform. Students are also provided with stimuli, enthusiasm, discourse, and motivation to learn these educational values before the lesson begins and during the face-to-face learning process in the classroom. The integration of cultural values and FC is expected to improve FC's quality and become a differentiating factor for FC because FCLCV is specially designed to build student character. An overview of the differences between the FC and FCLCV learning processes can be seen in Table 1. 
Table 1. The differences between the FC and FCLCV learning processes

\begin{tabular}{|c|c|c|}
\hline Stages & FC & FCLCV \\
\hline $\begin{array}{l}\text { Pre-Class } \\
\text { (Before } \\
\text { Class) }\end{array}$ & $\begin{array}{l}\text { - The students learn independently from } \\
\text { home using videos, PPT slides, } \\
\text { modules, and articles posted on } \\
\text { Edmodo. }\end{array}$ & $\begin{array}{l}\text { - The students learn independently from } \\
\text { home using videos, PPT slides, modules, } \\
\text { and articles posted on Edmodo. ** } \\
\text { - The students learn the Makassar- } \\
\text { Buginese educational values through the } \\
\text { Edmodo timeline and student worksheet } \\
\text { and try to implement the classroom } \\
\text { values.*/** }\end{array}$ \\
\hline In-Class & $\begin{array}{l}\text { - The lecturer clarifies the concept that } \\
\text { has been learned during the pre-class } \\
\text { online activity. } \\
\text { - The students solve problems and work } \\
\text { collaboratively to create presentation } \\
\text { materials. } \\
\text { - The students conduct presentations } \\
\text { and answer questions from other } \\
\text { students. } \\
\text { - The students do a reflection and } \\
\text { evaluation of their understanding of } \\
\text { the material. }\end{array}$ & $\begin{array}{l}\text { - The lecturer provides a stimulus for the } \\
\text { students about the Makassar-Buginese } \\
\text { educational values that can be } \\
\text { implemented in the classroom.*/** } \\
\text { - The lecturer clarifies the concept that has } \\
\text { been learned during the pre-class online } \\
\text { activity. */** } \\
\text { - The students solve problems and work } \\
\text { collaboratively to create materials for the } \\
\text { presentation.*/** } \\
\text { - The students conduct presentations and } \\
\text { answer questions from other students. } \\
\text { */** } \\
\text { - The students do a reflection and } \\
\text { evaluation of their understanding of the } \\
\text { material. * } / * *\end{array}$ \\
\hline After Class & $\begin{array}{l}\text { - The students do self-evaluation by } \\
\text { reviewing the material. } \\
\text { - The students do the assignment and } \\
\text { submit it to the lecturer via Edmodo. } \\
\text { - - }\end{array}$ & $\begin{array}{l}\text { - The students do self-evaluation by } \\
\text { reviewing the material. ** } \\
\text { - The students do the assignment and } \\
\text { submit it to the lecturer via Edmodo. }{ }^{*} \\
\text { - The students write a self-reflection note } \\
\text { about the character values that have been } \\
\text { implemented during the learning process } \\
\text { and upload their writing to Edmodo.** }\end{array}$ \\
\hline
\end{tabular}

NOTE

* The lecturer instills the Makassar-Buginese cultural values in students.

** The students implement educational values from the Makassar-Buginese culture, that are teppe, pesse, lempuk,sipakatau, sipakalebbi, sipakainge, sipatokkong,tongeng, reso, and abbulosibatang.

\section{METHODS}

\section{Type of the Study}

This study used a pretest-post-test non-equivalent control group design (Cohen, Manion, \& Morrison, 2011). There were three treatment groups involved in this study: the experimental group, the positive control group, and the negative control group. Integrated Flipped Classroom with Local Cultural Values (FCLCV) was applied in the experimental class, Flipped Classroom (FC) was implemented in the positive control class and Conventional (Direct Learning) was used in the negative control class. The FCLCV, FC, and Conventional (Direct Learning) learning models served as the study's independent variables, while student character was the study's dependent variable. The design of the study is presented in Table 2.

Table 2. Design of the study

\begin{tabular}{|l|l|l|}
\hline Pre-character & Model & Post-character \\
\hline 01 & FC & 02 \\
\hline 03 & FCLCV & 04 \\
\hline 05 & Conventional (Direct Learning) & 06 \\
\hline
\end{tabular}




\section{Population and Sample}

The study population was 2018-batch students from the Department of Biology Education, Universitas Negeri Makassar, South Sulawesi, Indonesia. The sample consisted of 35 students assigned to the Flipped Classroom (FC) group, 34 students assigned to the Integrated Flipped Classroom with Local Cultural Values (FCLCV) group and 33 students assigned to the Conventional (Direct Learning) group. The students were enrolled in the Animal Physiology course at the university. All of the participants were aged between 18-19 years old. A random sampling technique was used to select the sample who would participate in the homogeneity test using grouping test data.

\section{Instruments of the Study}

The students' character was observed using the observation sheets adopted from Bachtiar, Zubaidah, Corebima \& Indriwati (2018), Bulach (2002), and National (2011). The instrument used to observe the participants' character consisted of 7 indicators of character: honest, responsible, hard-working, ethical, tolerant, communicative, and collaborative. The assessment scale of the character ranged between 4.003.20 (very good), 3.19-2.80 (good), 2.79-2.40 (fair) and below 2.40 (poor). The assessment scale provided by the observers and students determined the total score of character on a series of items. The details on the character instrument can be seen in Table 3.

Table 3. Character Instrument

\begin{tabular}{|c|c|c|c|c|c|}
\hline \multirow{2}{*}{\multicolumn{2}{|c|}{ Honest }} & \multicolumn{4}{|c|}{ Score } \\
\hline & & \multirow[t]{2}{*}{1} & \multirow[t]{2}{*}{2} & \multirow[t]{2}{*}{3} & \multirow[t]{2}{*}{4} \\
\hline 1 & Always cite or mention sources to avoid plagiarism while writing & & & & \\
\hline 2 & Report objective data & & & & \\
\hline 3 & Admit limitations and errors in learning & & & & \\
\hline 4 & Receive credits for original works & & & & \\
\hline 5 & $\begin{array}{l}\text { Always speak the truth to friends regarding the material taught in the } \\
\text { classroom }\end{array}$ & & & & \\
\hline \multicolumn{2}{|c|}{ Responsible } & & & & \\
\hline 1 & Be responsible for group tasks & & & & \\
\hline 2 & Write a temporary report according to the practicum guidelines & & & & \\
\hline 3 & Perform the practicum based on the assigned role & & & & \\
\hline 4 & Report the practicum's findings based on facts & & & & \\
\hline 5 & Store the practicum equipment safely without being asked & & & & \\
\hline \multicolumn{2}{|c|}{ Hard-working } & & & & \\
\hline 1 & Actively search for information useful for learning & & & & \\
\hline 2 & Attempt to look for various alternatives to solve learning problems & & & & \\
\hline 3 & $\begin{array}{l}\text { Provide assistance for friends who have learning problems without asking } \\
\text { for anything in return }\end{array}$ & & & & \\
\hline 4 & Do not like to procrastinate & & & & \\
\hline 5 & Encourage and motivate friends to work together to achieve shared goals & & & & \\
\hline \multicolumn{2}{|r|}{ Ethical } & & & & \\
\hline 1 & Pay careful attention to friends, lecturers or professors when they speak & & & & \\
\hline 2 & Demonstrate humility in speaking to friends, lecturers or professors & & & & \\
\hline 3 & Implement $3 S$ (Salute, Smile, Say Hello). & & & & \\
\hline 4 & Thank someone for their help & & & & \\
\hline 5 & $\begin{array}{l}\text { Do not interrupt when someone is talking during a discussion and always } \\
\text { speak in a polite manner }\end{array}$ & & & & \\
\hline \multicolumn{2}{|r|}{ I 1} & & & & \\
\hline 1 & Respect others' opinions & & & & \\
\hline 2 & Accept a different agreement when discussing a topic & & & & \\
\hline 3 & Be open for new ideas and knowledge & & & & \\
\hline 4 & Forgive others' mistakes during a discussion & & & & \\
\hline 5 & $\begin{array}{l}\text { Be willing to work with anyone from different backgrounds or with anyone } \\
\text { who has different points of view or beliefs }\end{array}$ & & & & \\
\hline \multicolumn{2}{|c|}{ Communicative } & & & & \\
\hline 1 & Dare to express opinions in the classroom & & & & \\
\hline
\end{tabular}




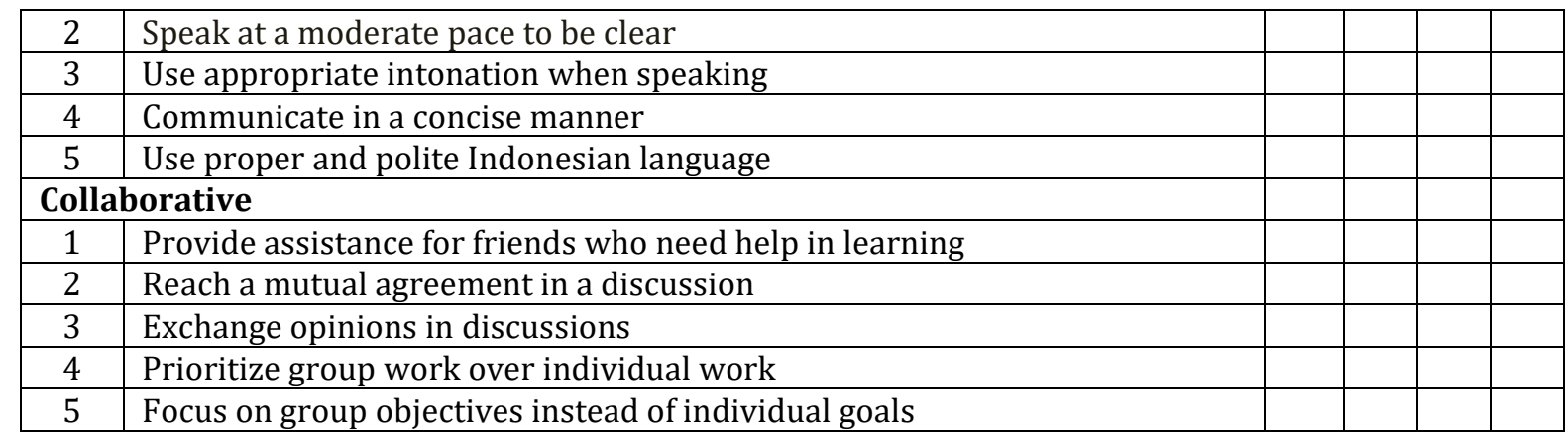

\section{Learning Procedures}

Each of the groups, namely Flipped Classroom (FC), Integrated Flipped Classroom with Local Cultural Values (FCLCV) and Conventional (Direct Learning) received different treatments in terms of learning process. The stages of learning carried out in the FC and FCLCV classes are explained in Table 1, while the learning process conducted in the Conventional (Direct learning) class was mostly dominated by discussion and question and answer sessions. In the Conventional class, the lecturer directed the students to present the material and organized discussion and question and answer sessions for them. At the end of the lesson, the lecturer provided reinforcement and the students listened carefully to the lecturer's information. Finally, together the lecturer and the students concluded the lecture. In conclusion, in the Conventional (Direct Learning) class, the lecturer played a more active or dominant role than the students.

\section{Data Collection and Data Analysis}

The data were collected through observations. The observations were conducted within a six-month period for 16 times/meetings. One observer was assigned to observe five students at most. The precharacter data were obtained from the first and second meeting observations, while the post-character data were gathered from the fifteenth and sixteenth meeting observations. The data were then analyzed using descriptive statistics and inferential statistics with one-way ANCOVA at the 5\% significance level. The analysis was continued with the LSD (Least Significance Different) test if there was a difference between the participants' character scores. The analysis of the data was assisted with SPSS for Windows. Prior to conducting the ANCOVA, the data normality and homogeneity were ensured through assumption tests. The data normality was examined using one-sample Kolmogorov-Smirnov test, while the data homogeneity was ensured using Levene's test of equality of error variances.

\section{RESULTS}

According to the statistical analysis results on the 16-meeting observations, the highest score in the FCLCV group (3.27) was observed in the honest indicator. At the same time, the lowest (3.06) was found in the communicative indicator. Meanwhile, the FC group achieved the highest in collaborative indicator with a score of 3.05, and the lowest in communicative indicator with a score of 2.71 . The highest score reported by the Conventional (Direct Learning) group was 2.93 (ethical) and the lowest was 2.53 (communicative). The FCLCV, FC, and Conventional (Direct Learning) students' mean scores on each indicator for 16 meetings are presented in Figure 7. 


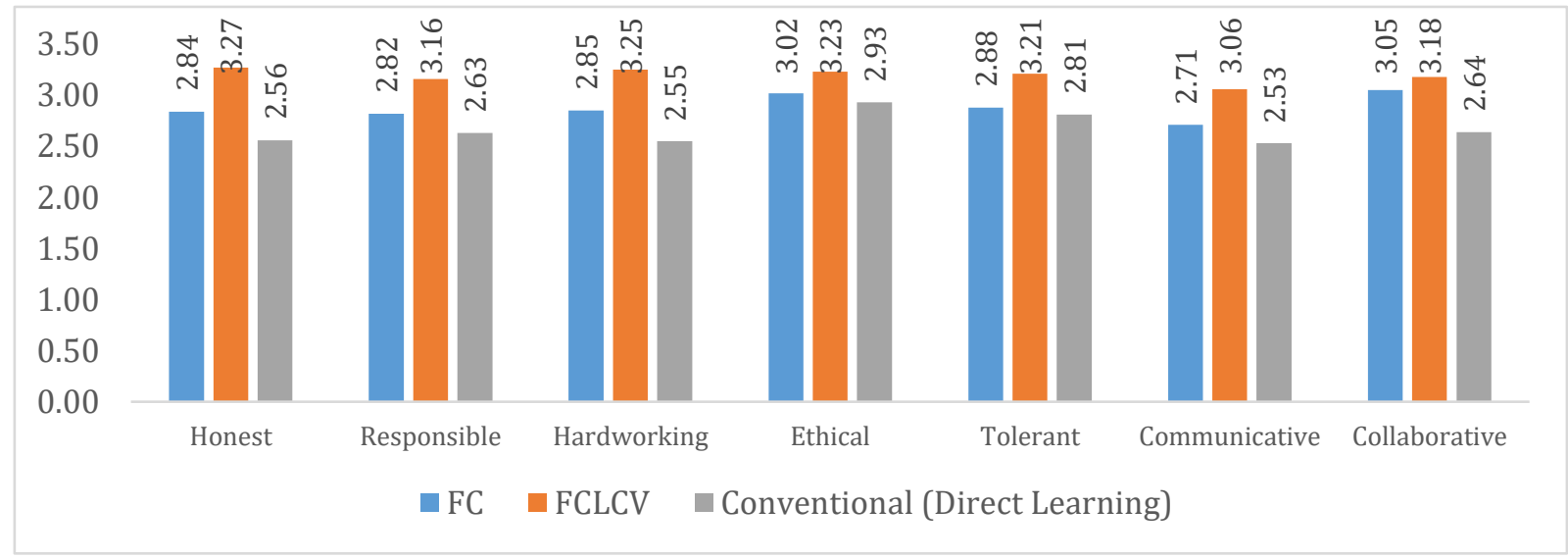

Figure 7. Mean scores achieved by the three treatment groups

Table 4 indicates an improvement in the mean scores achieved by the students in the FCLCV, FC and Conventional (Direct Learning) groups from pre-character to post-charater. The highest increase in the character score reported by students in the FCLCV group was 0.81 for honest indicator, while the lowest increase was 0.58 for the ethical indicator. Meanwhile, the FC students reported the highest increase in the collaborative indicator (0.53) and the lowest increase in the ethical indicator (0.39). Finally, the Conventional (Direct Learning) students reported the highest increase in the tolerant indicator (0.35) and the lowest increase in the ethical indicator (0.24).

Table 4. The increase in the character score reported by the three treatment groups

\begin{tabular}{|l|l|l|l|l|l|l|}
\hline Character & Model & $\mathrm{N}$ & $\begin{array}{l}\text { Pre- } \\
\text { character }\end{array}$ & $\begin{array}{l}\text { Post- } \\
\text { character }\end{array}$ & $\begin{array}{l}\text { N- } \\
\text { Gain }\end{array}$ & Criteria \\
\hline \multirow{3}{*}{ Honest } & FC & 35 & 2.15 & 3.05 & 0.49 & Medium \\
\cline { 2 - 7 } & FCLCV & 34 & 2.01 & 3.62 & 0.81 & High \\
\cline { 2 - 7 } & Conventional & 33 & 2.04 & 2.71 & 0.34 & Medium \\
\hline \multirow{4}{*}{ Hesponsible } & FC & 35 & 2.26 & 3.03 & 0.44 & Medium \\
\cline { 2 - 7 } & FCLCV & 34 & 2.37 & 3.47 & 0.67 & Medium \\
\cline { 2 - 7 } & Conventional & 33 & 2.22 & 2.72 & 0.28 & Low \\
\hline \multirow{5}{*}{ Ethical } & FC & 35 & 2.04 & 3.06 & 0.52 & Medium \\
\cline { 2 - 7 } & FCLCV & 34 & 2.02 & 3.45 & 0.72 & High \\
\cline { 2 - 7 } & Conventional & 33 & 2.09 & 2.61 & 0.27 & Low \\
\hline \multirow{5}{*}{ Communicative } & FC & 35 & 2.93 & 3.35 & 0.39 & Medium \\
\cline { 2 - 7 } & FCLCV & 34 & 2.86 & 3.52 & 0.58 & Medium \\
\cline { 2 - 7 } & Conventional & 33 & 2.83 & 3.11 & 0.24 & Low \\
\hline & FC & 35 & 2.45 & 3.15 & 0.45 & Medium \\
\cline { 2 - 7 } & FCLCV & 34 & 2.49 & 3.56 & 0.71 & High \\
\cline { 2 - 7 } & Conventional & 33 & 2.41 & 2.96 & 0.35 & Medium \\
\cline { 2 - 7 } & FCLCV & 35 & 2.28 & 2.98 & 0.41 & Medium \\
\cline { 2 - 7 } & Conventional & 33 & 2.21 & 3.32 & 0.62 & Medium \\
\hline \multirow{3}{*}{ Collaborative } & FC & 35 & 2.58 & 2.69 & 0.28 & Low \\
\cline { 2 - 7 } & FCLCV & 34 & 2.60 & 3.58 & 0.53 & Medium \\
\cline { 2 - 7 } & Conventional & 33 & 2.29 & 2.71 & 0.70 & High \\
\hline
\end{tabular}

The ANCOVA result (Table 5) showed that FC, FCLCV, and Conventional (Direct Learning), had a significant effect on student character with a significance value of $p=0.000(p<0.05)$. 
Table 5. The Result of ANCOVA on the effect of learning models on student character

\begin{tabular}{|l|l|l|l|l|l|}
\hline Source & Type III Sum of Squares & df & Mean Square & F & Sig. \\
\hline Corrected Model & $15.296^{\mathrm{a}}$ & 3 & 5.099 & 92.472 & .000 \\
\hline Intercept & 1.006 & 1 & 1.006 & 18.238 & .000 \\
\hline Pre-character & 6.707 & 1 & 6.707 & 121.650 & .000 \\
\hline Learning Model & 7.005 & 2 & 3.503 & 63.527 & .000 \\
\hline Error & 5.403 & 98 & .055 & & \\
\hline Total & 1030.590 & 102 & & & \\
\hline Corrected Total & 20.699 & 101 & & & \\
\hline
\end{tabular}

LSD test was conducted to investigate the significance of the difference between the treatment groups' mean scores. In Table 6, the LSD notations suggest that the FCLCV group differed significantly from the FC and Conventional (Direct Learning) groups in terms of character. The pre-post character improvement (47.67 \%) and mean score (3.50) achieved by the FCLCV group were higher than those obtained by the FC group $(31.51 \%$ and 3.13$)$ or the Conventional (Direct Learning) group $(21.39 \%$ and 2.78). This result indicates that FCLCV contributed significantly to the improvement of student character.

Table 6. The result of the LSD test on the effect of learning models on student character

\begin{tabular}{|l|l|l|l|l|l|l|}
\hline Model & $\begin{array}{l}\text { Pre- } \\
\text { character }\end{array}$ & $\begin{array}{l}\text { Post- } \\
\text { character }\end{array}$ & Deviation & $\begin{array}{l}\text { Increase } \\
(\%)\end{array}$ & $\begin{array}{l}\text { Mean } \\
\text { score }\end{array}$ & $\begin{array}{l}\text { LSD } \\
\text { Notation }\end{array}$ \\
\hline FC & 2.38 & 3.14 & 0.75 & 31.51 & 3.13 & $\mathrm{a}$ \\
\hline FCLCV & 2.37 & 3.50 & 1.13 & 47.67 & 3.50 & $\mathrm{~b}$ \\
\hline Conventional (Direct Learning) & 2.29 & 2.79 & 0.49 & 21.39 & 2.78 & $\mathrm{c}$ \\
\hline
\end{tabular}

\section{DISCUSSION AND CONCLUSIONS}

Advances in science and technology must be accompanied by character education to enhance human resources quality and noble character. This study showed that Integrated Flipped Classroom with Local Cultural Values (FCLCV) was more effective than Flipped Classroom (FC) and Conventional (Direct Learning) in improving student character. The highest mean score achieved by students in the FCLCV was observed in the honest indicator. The FCLCV students also reported excellent hard-working, ethical, and tolerant scores. However, in responsible and collaborative indicators, the FCLCV and FC students achieved scores in the same category (good category). It happened because the instructional models were both based on cooperative learning principles that emphasize collaboration and mutual support (Sengel, 2016). Unlike FCLCV and FC, the Conventional (Direct Learning) students improved only in two indicators: ethical and tolerant.

Compared to the FC and Conventional (Direct Learning) students, students in the FCLCV group could obtain higher mean scores in character indicators because FCLCV integrates the Makassar-Buginese cultural values into the learning process. The local culture's educational values can be used to shape student character (Kristjánsson, 2020). Unlike FCLCV and Conventional (Direct Learning), FC is not combined with educational cultural values that can be used to improve student character. However, the collaboration activity embedded in both FC and FCLCV enables the students to develop cooperative character traits (Bachtiar et al., 2018; Suhirman \& Yusuf, 2020). Collaborative learning can improve and establish social relationships between students (Slavin, 2010). According to Joyce and Emily (2009), the collaborative activity can also increase student responsibility, mutual respect, complementary views of others, and reduce unhealthy competition among students. In conventional (Direct Learning), students are not allowed to improve character because this learning model cannot actively involve students in the learning process. In fact, active student involvement through learning activities can support character building (Komalasari \& Saripuddin, 2017).

The FCLCV learning process consists of three stages, namely pre-class, during class, and after class. Each step plays a vital role in shaping student character. In the pre-class stage, the lecturer embeds the Makassar-Buginese cultural values to the Edmodo timeline and student worksheet to read and understand the values before conducting learning in the classroom. This pre-class activity helps increase student awareness of what kind of attitudes they need to develop during the learning process (Baehr, 2017). Besides, the during class activity emphasizes the provision of stimulus and encouragement for the students regarding implementing the cultural value. During the in-class process, character-building becomes more effective due to the lecturer's affectionate and comforting delivery values. Finally, at the 
after-class stage, the students are asked to write a self-reflection note about what character values they have implemented in the classroom and submit the note via Edmodo to be reviewed by the lecturer.

In FCLCV, the lecturer plays an essential role in shaping the students' character at every learning stage. The lecturer needs to establish a social relationship with the students to improve and strengthen their character through problem-solving, classroom discussion, question and answer sessions, presentations, or task assignment. The lecturer also needs to remind the students about the MakassarBuginese cultural values integrated in learning. These values include pesse (compassion), lempuk (honesty, straightening deeds and intentions), sipakatau (humanizing humans), sipakalebbi (glorifying humans), sipakainge (mutual reminding), sipatokkong (mutual help and mutual support), tongeng (sincerity), reso (hard work), and abbulosibatang (collaboration). Repeated teachings of cultural values in the classroom can bring about changes in student attitudes. Students become accustomed to implementing cultural values and become increasingly skilled at applying them (Engelen, Thomas, Archer, \& Ven, 2018). Students eventually show behavior that suggests "shame" towards themselves, towards other students or their lecturers if they fail to apply the Makassar-Buginese educational values in the classroom. These behaviors are the key to changing student character during the learning process.

This result is in accordance with the character education suggested by the Makassar-Buginese culture. People who understand their culture will feel ashamed if they fail to apply or heed their culturaleducational values in their daily lives (Mattalitti, 2014). According to the Makassar-Buginese society, people who do not feel ashamed are people who do not have faith. People like this are commonly referred to as the "living dead". They are also considered as despicable people (Rahim, 2011). Therefore, students' character can be changed for the better through a character education process that integrates the Makassar-Buginese educational values. Presenting quality character education is not an easy thing. Character development requires habituation, namely habituation to do good, right and beautiful deeds and being accustomed to feeling ashamed when doing something that is contrary to the ideology of the nation, religion and culture (Tannir \& Al-Hroub, 2013).

The significant influence on students' character building in FCLCV is that the model focuses on attitude formation. The learning process that pays more attention to the formation of the realm of attitudes will impact students' character building (Izzati, Surabaya, Bachri, Surabaya, \& Indriani, 2019; Nurochim, Mujahidin, Purwoko, Asy'Ari, \& Muksin, 2020). The Makassar-Buginese culture integrated into FCLCV is rich with educational values taught to Makassar-Buginese people from generation to generation to be always motivated to do good and be good (Abbas, 2013; Akib, 2016). The relationship between stimuli and responses becomes much more robust when training is provided (Behlol, 2010).The integration of local cultural values into learning is one way of character education that can give birth to generations who make culture a guide for life. Character education based on ethnopedagogy can positively impact students' and educators' school climate, morals, and behavior (Christen, 2018).

The distinctive characteristics of FC also contribute to the character-building process accommodated in FCLCV. Flipped Classroom (FC) is seen as an instructional model that offers independent learning, group cooperation, problem-solving, and the right social interaction processes to students so that they can form self-regulation, trust, and motivate each other (Munir et al., 2018; Yildiz, 2020; Zarouk et al., 2020). According to Akcayir \& Akcayir (2018), FC can also shape students' personality, increase their creativity, develop their focus on an issue, increase their self-confidence, foster a sense of responsibility and hard work, and create positive perceptions and attitudes towards the learning process. $\mathrm{FC}^{\prime} \mathrm{s}$ positive traits can help shape student character even though it is still limited to certain characters compared to FCLCV.

In general, FCLCV can improve student character. The problems in the field, especially those related to character crises, will not impact education if they can be appropriately handled. However, "preventing" a character crisis is more important than "overcoming" or "treating" it. In addition, the use of technology, which is said to be an obstacle or the cause of the decline in the student character, is no longer a problem. Engelen et al. (2018) argue that students must be fully aware of the consequences of their actions to avoid doing something that contains negative values. Suppressing negative desires can form superior quality students (Kristjánsson, 2020)

Local cultural values play an essential role in shaping a person's character to be integrated into learning. This study's limitations are that it only involved participants and the local cultural values from South Sulawesi. Future research needs to consider whether FCLCV effectively builds students' character from different cultural backgrounds. Therefore, FCLCV needs to be tested in other areas. 


\section{ACKNOWLEDGMENT}

This study was funded by the Ministry of Research and Technology/National Research and Innovation Agency through a doctoral dissertation research grant with Contract No. 10.3.46/UN32.14/LT/2020. Sincere gratitude should be given to the Faculty of Mathematics and Natural Sciences of Universitas Negeri Malang and the Department of Biology of Universitas Negeri Makassar, Indonesia.

\section{REFERENCES}

Abbas, I. (2013). Pappaseng: Kearifan lokal manusia bugis yang terlupakan. Sosiohumaniora, 15(3), 272284.

Abdullah, M. Y., Hussin, S., \& Ismail, K. (2019). Implementation of flipped classroom model and its effectiveness on English speaking performance. International Journal of Emerging Technologies in Learning, 14(9), 130-147.

Agustang, K. (2018). Korelasi petuah bugis pappaseng dengan hadis-hadis tarbawi (telaah catatan mappiase gule dalam 100 ada-ada pappaseng toriyolo). Jurnal Islamika: Jurnal Ilmu-Ilmu Keislaman. 18(1).

Akçayir, G., \& Akçayir, M. (2018). The flipped classroom: A review of its advantages and challenges. Computers \& Education, 126(August), 334-345.

Akib, I. (2016). The description of relationship between mathematics characteristic and Bugis Culture values. Global Journal of Pure and Applied Mathematics, 12(4), 2765-2775.

Arsih, F., Zubaidah, S., Suwono, H., \& Gofur, A. (2019). The exploration of educational value in Randai Minangkabau Art, Indonesia. Journal for the Education of Gifted Young Scientists, 7(4), 1225-1248.

Arwita, W., Amin, M., Susilo, H., \& Zubaidah, S. (2017). Integrating the social interaction system of dalihan na tolu into the problem based learning on biology subjects to increase students' achievement. International Journal of Science and Research, 6(1).

Awidi, I. T., \& Paynter, M. (2019). The impact of a flipped-classroom approach on student learning experience. Computers \& Education, 128, 269-283.

Bachtiar, S., Zubaidah, S., Corebima, A. D., \& Indriwati, S. E. (2018). The spiritual and social attitudes of students towards integrated problem based learning models. Issues in Educational Research, 28(2), $254-270$

Baehr, J. (2017). The varieties of character and some implications for character education. Journal of Youth and Adolescence, 1-8.

Behlol, M. G. (2010). Concept of learning. International Journal of Psychological Studies, 2(2), 231-239.

Bulach, C. R. (2002). Implementing a character education curriculum and assessing its impact on student behavior. A Journal of Educational Strategies, Issues and Ideas, 76(2), 79-83.

Choli, I., \& Raihan. (2020). Factors That Influence the Character of Students in School. Journal of Educational and Social Research, 10(3), 105-114.

Christen, M. (2018). Comparing cultural differences with domain-specific differences of appreciating and understanding values. Journal of Moral Education, 1-21.

Cohen, L., Manion, L., \& Morrison, K. (2011). Research Methods in Education 7th edition. New York: Routledge.

Engelen, B., Thomas, A., Archer, A., \& Ven, N. Van De. (2018). Exemplars and nudges : Combining two strategies for moral education. Journal of Moral Education, 1-20.

Erbil, D. G., \& Kocabas, A. (2019). Primary teachers' views on using technology in education, flipped classroom and cooperative learning. Elementary Education Online, 18(1), 31-51.

Hamid, A., Farid, Z. A., Mattulada, Lopa, B., \& Salombe, C. (2003). Siri' \& Pesse: Harga Diri Manusia Bugis, Makassar, Mandar, Toraja. Makass: Pustaka Refleksi.

Hidayati, N. A., Waluyo, H. J., Winarni, R., \& Suyitno. (2020). Exploring the implementation of local wisdom-based character education among indonesian higher education students. International Journal of Instruction, 13(2), 179-198.

Hsieh, J. S. C., Wu, W. V., \& Marek, M. W. (2017). Using the flipped classroom to enhance EFL learning. Computer Assisted Language Learning, 30(1-2), 1-21.

Isawi, H., AlAhmad, A., Alsaadi, A., \& Samkari, H. (2019). The effects of information technology on the role of emotions in acquisition and transmission of moral knowledge. Science Studies: An Interdisciplinary Journal for Science and Technology Studies, 13(1), 103-112.

Izzati, U. A., Surabaya, U. N., Bachri, B. S., Surabaya, U. N., \& Indriani, D. E. (2019). Character education : Gender differences in moral knowing, moral feeling, and moral action in elementary schools in Indonesia. Journal for the Education of Gifted Young Scientists, 7(3), 547-556. 
Joyce, M., \& Emily. (2009). Models of teaching (Teaching Models) (8th ed.; A. Fawaid \& A. Mirza, Ed.). Yogyakarta: Student Library.

Judi, H. M., Ashaari, N. S., Azan, N., Zin, M., \& Yusof, Z. M. (2013). Framework of ICT impact on adolescent. Procedia Technology, 11, 1034-1040.

Kelemen, T. K., Matthews, S. H., \& Breevaart, K. (2020). Leading day-to-day: A review of the daily causes and consequences of leadership behaviors. The Leadership Quarterly, 31(1).

Khan, I. A., Asif, F., Hashmi, Q. I., \& Azeddou, N. (2017). Factors affecting integration of local culture in Saudi English language classrooms. European Journal of Education Studies, 3(4), 682-703.

Komalasari, K., \& Saripuddin, D. (2017). Value-based interactive multimedia development through integrated practice for the formation of students' character. The Turkish Online Journal of Educational Technology, 16(4), 179-186.

Komalasari, K., \& Saripuddin, D. (2018). The influence of living values education-based civic education textbook on student's character formation. International Journal of Instruction, 11(1), 395-410.

Kristjánsson, K. (2020). An introduction to the special issue on wisdom and moral education. Journal of Moral Education, 49(1), 1-8.

Kustandi, C., Warhahadibraka, Fadhillah, D. N., Suprayekti, \& Nursetyo, K. I. (2020). Flipped classroom for improving self-regulated learning of pre-service teachers. International Journal of Interactive Mobile Technologies, 14(9), 110-127.

Leo, J., \& Puzio, K. (2016). Flipped instruction in a high school science classroom. Journal of Science Education and Technology, 25(5), 775-781.

Lickona, T. (1991). Educating for Character: how our school can teach Respect and Responsibility. New York, Toronto, London, Sidney, Auckland: Books.

Lo, J. H., Fu, G., Lee, K., \& Cameron, C. A. (2019). Development of moral reasoning in situational and cultural contexts. Journal of Moral Education, 1-17.

Mattalitti, A. (2014). Meniti Siri' dan Harga Diri. Buku Oktobiografi. Jakarta.978-979-97305-0-3.

Mattulada. (2015). Latoa: Antropologi Politik Orang Bugis. Makass: Ombak.

Mislia, Mahmud, A., \& Manda, D. (2016). The implementation of character education through scout activities. International Education Studies, 9(6), 130-138.

Munir, M. T., Baroutian, S., Young, B. R., \& Carter, S. (2018). Education for chemical engineers flipped classroom with cooperative learning as a cornerstone. Education for Chemical Engineers, 23, 25-33.

Nasional, K. P. (2011). Panduan pelaksaan pendidikan karakter. Jakarta: Kementrian Pendidikan Nasional.

Nurochim, Mujahidin, E., Purwoko, D., Asy'Ari, H., \& Muksin. (2020). Development on educational management and cultural integration of pesantren based school in Indonesia context. Elementary Education Online, 19(4), 104-114.

Rahim, A. R. (2011). Nilai-Nilai Utama Kebudayaan Bugis. Ujungpandang: Lembaga Penerbitan Universitas Hasanuddin.

Ristiana, E., Amin, M., Zubaidah, S., Heni, M., \& Al, I. (2017). Improving problem-solving ability through culture-based learning model of Tudang Sipulung. IOSR Journal of Pharmacy and Biological Sciences, 12(3), 11-14.

Santikarn, B., \& Wichadee, S. (2018). Flipping the classroom for English language learners : A study of learning performance and perceptions. International Journal of Emerging Technologies in Learning, 13(9), 123-135.

Sengel, E. (2016). To FLIP or not to FLIP: Comparative case study in higher education in Turkey. Computers in Human Behavior, 64, 547-555.

Sikki, M., Rijal, S., Nasruddin, \& Alam, S. (1998). Nilai dan Manfaat Pappaseng dalam Sastra Bugis. Jakarta: Pusat Pembinaan dan Pengembangan Bahasa.

Silay, N. (2013). Character education at Universities. Journal of Educational and Social Research, 3(1), 4350.

Slavin, R. E. (2010). Cooperative learning: Theory, Research and Practice. Translated by Narulta Yusron. Bandung: Publisher Nusa Media.

Suastra, I. W. (2017). Balinese local wisdom and their implications in science education at school. International Research Journal of Management, IT \& Social Sciences Available, 4(2), 48-57.

Suhirman, \& Yusuf. (2020). The effect of problem-based learning with character emphasis toward students' higher-order thinking skills and characters. International Journal of Emerging Technologies in Learning, 15(6), 183-191.

Suyatno, Jumintono, Pambudi, D. I., Mardati, A., \& Wantini. (2019). Strategy of values education in the Indonesian education system. International Journal of Instruction, 12(1), 607-624.

Suyitno, H., Zaenuri, Sugiharti, E., Suyitno, A., \& Baba, T. (2019). Integration of character values in teaching-learning process of mathematics at elementary school of Japan. International Journal of 
Instruction, 12(3), 781-794.

Tannir, A., \& Al-Hroub, A. (2013). Effects of character education on the self-esteem of intellectually able and less able elementary students in Kuwait. International Journal of Special Education, 28, 47-59.

Taufiqurrahman. (2018). Pembentukan karakter mahasiswa dalam sistem pendidikan tinggi Islam. Tadris, 12(1).

Umami, I., Gani, A., \& Waskito, T. (2019). Proposal of character and moral education for gifted young scientists in Indonesia. Journal for the Education of Gifted Young Scientists, 7(2), 377-387.

Unru. (2018). Memahami budaya 3-S (Sipakatau, Sipakalebbi dan Sipakainge). Makassar: Universitas Hasanuddin.

Wang, J., Jou, M., Lv, Y., \& Huang, C. (2018). An investigation on teaching performances of model-based flipping classroom for physics supported by modern teaching technologies. Computers in Human Behavior, 84, 36-48.

Yildiz, Y. (2020). Examining the effect of flipped learning model in flute education on motivation and performance of students. Elementary Education Online, 19(4), 2347-2369.

Zainuddin, Z., \& Perera, C. J. (2017). Exploring students ' competence, autonomy and relatedness in the flipped classroom pedagogical model. Journal of Further and Higher Education, 1-12.

Zarouk, M. Y., Olivera, E., Peres, P., \& Khaldi, M. (2020). The impact of flipped project-based learning on self-regulation in higher education. International Journal of Emerging Technologies in Learning, 15(17), 127-147. 